商分子文集 (Kobunshi Ronbunshu)，Vol. 36, No. 5, pp. 287-292 (May, 1979)

\title{
部分エステル化ポリヒニルアルコール水溶液のポリメタクリル酸 によるこ位差淌定
}

堀内 裕治*1

(受付 1978 年 8 月 9 日・䕰查終了 1978 年 11 月 1 日)

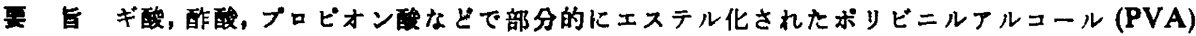

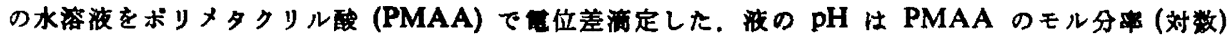

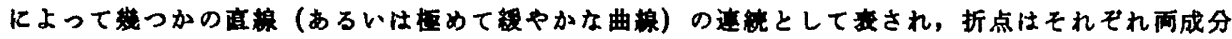

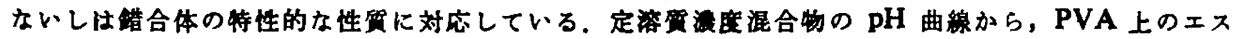
テル基が分子全体としては PVA の㙁基性を䏆大させて PMAA との相互作用を大きくするが， 一

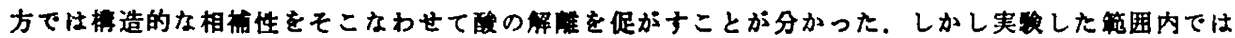
两者仕等モルの錯合体を形成するといえる。等度の测定結果もこれを支持する。両成分混合系の相

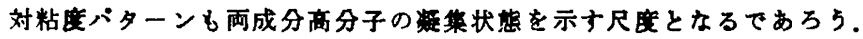

\section{1 曹}

水容夜内における高分子と高分子の相互作用，あるい

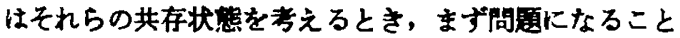
の一つは各成分高分子が電解筫か否かといらことであろ 5. 両者とむに䉓解質である場合には研究例の大部分を 占めるのは反対荷奄の強, あるいは弱奄解質の組合せで あって，基本的にはこれらは高分子-高分子塩 (polypoly salt) である. 高分子錯体の中K恃高分子が眠位子 となる金属錯化合物る特に醭菜反応の機作と成連して 大きい分野を占めるはずのるのがあるから，ここでは高 分子-高分子の場合を complex-associate の意味で錯 合体と呼ぶことにする．高分子龟解質錯 合体（poly electrolyte complex, PEC) の中Kむ錯合体の安定化 に対して水秦結合が本質的な役割る果しているすのすあ グ，この場合にはカ山ボキシル基どらしが分子间の相 互作用に関与する，これらとは别に，合成ボリェーテル中 ボリフルコールあるいは多結頼などの非電解質とタンパ ク質や合成高分子電解質の組合せ，および非䉓解質高分 子どらしの間です，錯合体の礁認は困難であるにせよ錯 合体形成の可能性を否定することもできないであろう. これらはいわばそれぞれ高分子電解貿一高分子非電解貿 錯合体 [poly (electrolyte-nonelectrolyte) complex, PENC) おょび高分子非龟解質錯合体（poly (nonelectrolyte) complex, PNC] と呼らことができる.

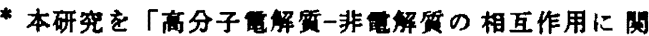
す万研究第 2 報」とする

*1 要泼大学理学部化学科 (-790 松山市文京町 2)
}

筆者は先に PVA-PMAA の相互作用の研究から前者 が高分子酸に対して一種の塩基的な举動をとることを報 告した ${ }^{22}$. 本報においては PVA の一部がギ酸ないしブ ロピオン酸でエステル化された中性高分子の PMAA に 上る $\mathrm{pH}$ 滴定その他からェステル化が PVA の錯合体 形成能に及ぽす影敏を調へたいと思ら。

\section{2 実験}

\section{1 猃料ボリマー}

部分エステル化 PVA は公称重合度 500 の市股ポリ ビニルアルコール (半井化学菜品(株)慗, 残存酢酸基 $10.8 \mathrm{~mol} \%$ ）をアルカリけん化，再沈殿後水溶液とし これに適当量の有機酸之塩酸を加えて加温する均一系エ ステル化によってっくった，いずれの試料も水溶性であ る. ギ醊，䣫醊，プロピオン酸の残基をそれぞれ F， Ac, $\operatorname{Pr}$ で表し，その含有率 (mol\%) をPVA (Pr, 4.5) などの上5に数字で示す．又，エステル基を含まないも のを PVA (0)，一般に部分エステル化物も含めて PVA と記すことにする。

ポリオキシェチレン, PEG，分子量 20000 (和光純菜 工羓(株)製）は市肘品を固形水酸化ナトリウム上で煘圧 䩐燥したものをそのま用いた。

PMAA は前報と同じもの で份別物，重合度（粘 度) 8020 である。

\section{2 請測定}

粘度， $\mathrm{pH}$ の㑚定はそれぞれ，(株)東京計器製コーン フレーート型回転粘度計 ELD 型ならびに 東严電波工業 (株) 製 HM 5A 型 pH メーターに一般用一本型ガラ 
ス・比较䉓極を用いて測定した。

滴定用 PVA 水容液の液性が酸側に大きく㑯いている ときは，よく水洗した OH 型陰イオン交換㴻脂屏を通し $\tau \mathrm{pH} \sim 6.4$ 以上に調整し，乾固法による浱度決定後希 积して実駼に供した。

電尊度は (株) 柳本製作所製電気電尊測定装置 MY-8 および内容量約 $30 \mathrm{ml}$ の Freas 型電幕度セルで湘定し た。

\section{3 桔果と考夷}

\section{$3.1 \mathrm{pH}$ 滴定曲租}

\subsection{1 $f_{\mathrm{A}}$ ブロット}

PVA の水湻液に PMAA 水溶液を順次に滴加した场 合の $\mathrm{pH}$ 湘定值を，各時点において容液中に存在する 2 種の高分子のうち PMAA のモル分事(対数)， $f_{\mathrm{A}}(\mathrm{log})$ ， に対してブロットしたのの数例を Fig. 1 に示す. 横軸の $f_{\Lambda}$ は，系の $\mathrm{pH}$ に直接に闺㐿寸る酸浱度， [PMAA]—この場合には共存する PVA の㱏は無視 される一と違って分率であるので，これを用いる理論

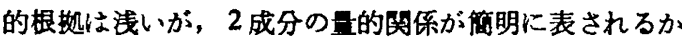
ら相互作用を考察する上では意味がある。この表現によ れば PVA の PMAA による pH 滴定曲線は幾つかの 直線（あるいは極めて綏やかな曲線）の部分から成るこ とが分かる. PVA のエステル化度, エステルの種類, 初渄度などによって曲線は多槏であるが，それらに共通 な特長として $f_{\Delta}=0.4 \sim 0.6$, 大部分は 0.5 の所に屈折 点を持つことが举げられる.この 0.5 はビニルフルコ 一ルとビニルエステルとを区別せずに 1 単位として数え て, これらと添加されたカルボキシル基の数が等しい組 成の点一これを $f_{1 / 2}$ とする一ててある，経鍳的には PVA の初算度が低い方が折点も0.5になりやすいが， 一方ではその低い PVA 初浱度に応して PMAA の䈨 度も低くなるから折点が不めいりょらになる。

Fig. 1 の曲線上に矢印で示した組成点は系内の (PVA 上の）エステル基の贯と滴加されたカルボキシル基の量 とが等しくなった時点に批ける酸のモル分事一ここれ $f^{*}$ とする一表す. $f^{*}$ の前後に批る $\mathrm{pH}$ 曲線の変 化は様々であり特に折点と見られないものてあるが, 全 体としてみると, 同一エステル種ではェステル含有率の 高いものに批いて, 又, 初湛度の高いるのにおいて, $f *$ 近傍を折点とする例が見られるよらである.これらの折 点, あるいは接綂点 (connecting point) はいわば end of similar state (of interaction) と見ることができる から， $f_{1 / 2}$ に対応して，エステル基の有無にかかわらず PVA とPMAA とはモノマー単位 1:1を境にしてそ の相互作用の仕方が変わる，あるいは両成分恃等モル錯 合体を形成することが推測される， $f^{*}$ に関連してはカ ルボキシルーエステルとカルボキシルーヒドロキシルの 2

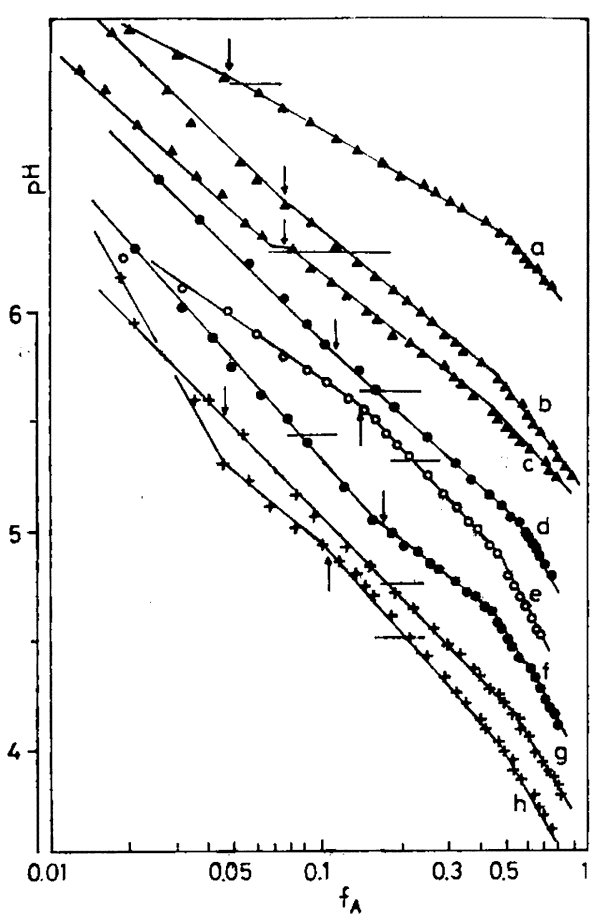

Fig. 1. Potentiometric titrations of partly esterified PVA with PMAA at room temperature: $f_{\mathbf{A}}$, mole fraction of PMAA in the mixture; $\uparrow$, the $f_{A}$ where PMAA is added equivalent to ester groups in the system. $\mathrm{pH}$ is indicated only for lowest curve (h). Horizontal line across the curve indicates the point at $\mathrm{pH}=4.5$. Content of ester group (mol\%), initial concentration of PVA, and concentration of titrant $(\mathrm{mol} / \mathrm{l}): \mathrm{a}, 4.9,0.05$, and $0.082 ; b, 7.5,0.02$, and $0.082 ; c, 7.5$, 0.05 , and $0.082 ; d, 12.6,0.05$, and 0.082 ; $e$, $15.8,0.05$, and $0.082 ; f, 20.3,0.05$, and $0.082 ; g, 4.5,0.012$, and $0.077 ; h, 11.6,0.011$, and 0.077 . $\Delta$, formate; 0,0 , acetate; + , propionate.

組の相互作用の佌先性を論していることになるわけであ るが，前者が後者に比へて䏅立って大きい相互作用をも ち、それが空間的にも許されるならば折点の一つとして の $f^{*}$ がありらることになる.

ところでここにおいて，エステルとカルボキシルとの 相互作用が強いのであれば, 後に PEG-PMAA 系で見 るように pH 曲線の傾斜は $0<f_{\mathbf{A}}<f^{*}$ の箅团で小さい はずであると考えることむできるが，現実には大きい值

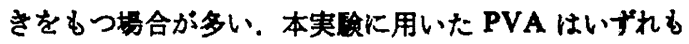
完全けん化物を均一系で再エステル化したものであるか 
らエステル基分布にブロック性が少なく、ランダムな分 布であるとみてよいる．これは又，ビ二ルアルコールと ピニルメステルの単位がそれぞれ反応速度定数比 1 を以 てボリマー組成に対応する量だけ共重合したものと考え ることができるから， sequence distribution に夙する バダサリヤンの式)を利用してェステル基の連（n 個 の連繶したェステル基の分布) を計算すると，例えば 7.5\% のエステル基を含むPVA 上で性全エステルの 85\% あまりが両隣りに水䤑基をもっていることになる し, エステル基 $20.3 \mathrm{~mol} \%$ ではその5ちの 63\% が扔 立している. 同一分子上に多数存在する $\mathrm{OH}$ 基によって 様々な程度に槅てられたこれらのエステル基が短い定间 隔で並んだ PMAA のカルボキシル基と相互作用するわ けであるから PVA は無理な配座をとらざるを゙ず，て れだけ $\mathrm{COOH}$ は「捕われない」状態になりやすいと考 えられる.一方，分子全体として見たときは，かさ高い アシル基が両成分高分子の密接を妨げることにも倒くで あろ5。

$f^{*}$ から $f_{1 / 2}$ へかけては系中の $\mathrm{COOH}$ の增加に伴っ て両成分単位どうしの対形成過程であり，いずれる規則 正しい pH 变化をする， 叉，PVA の代わりに $\mathrm{NaOH}$ を PMAA で谪定した場合には $\mathrm{pH} \sim f_{\Delta}(\mathrm{log})$ 曲線は極 めて小さい初期㑯斜をもち， $f_{1 / 2}$ で大幅な $\mathrm{pH}$ の垂直降 下がある。

pH の折点がその他の理由からも生じるものであろら ことは PVA(0) について同棣の曲線を描いてろると明 らか炏なる。 この場合 $\mathrm{pH}$ の変化は滴定条件によって $f_{\Delta}$ が 0.14 ないし 0.2 の付近, すなわち, PVA : PMAA = 6 4:1 のモル比のところまでは傾斜が大き

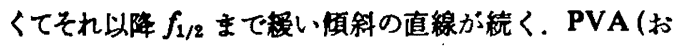
よひ PMAA) の配座の変化む pH 曲線の折点をむたら ナ一つの因子となるであろう。

\subsection{2 別法によるブロット}

本報のよらな仕方では pH は高分子酸あるいはこれと 中性高分子の相互作用生成物の解噰にの子依存するので あるから，pH のブロットも当然 [PMAA] に対して行 すべきである，それを両高分子成分の実駼値を使って表 現すると次のよ5になる。初港度 $L_{0}$ (base-mol $/ l$ ) の PVA $V_{\mathrm{l}}(\mathrm{m} l)$ に湿度 $A_{0}$ の PMAA $V_{\mathrm{A}}$ たけ滴加し た時点における酸の洤度を $A_{\mathfrak{t}}$ とすれば, 液量の加成性 を仮定し， $L_{0} / A_{0}=r$ とおくと

$$
A_{\mathrm{t}}=\frac{A_{0} V_{\mathrm{A}}}{V_{\mathrm{L}}+V_{\mathrm{A}}}, \quad f_{\mathrm{A}}=\frac{A_{0} V_{\mathrm{A}}}{L_{0} V_{\mathbf{L}}+A_{0} V_{\mathrm{A}}}
$$

から,

$$
A_{\mathrm{t}}=\frac{L_{0} f_{\mathrm{A}}}{1-(1-r) f_{\mathrm{\Delta}}}
$$

が得られる. 式 (1)の $L_{0}$ を除いた部分を modified

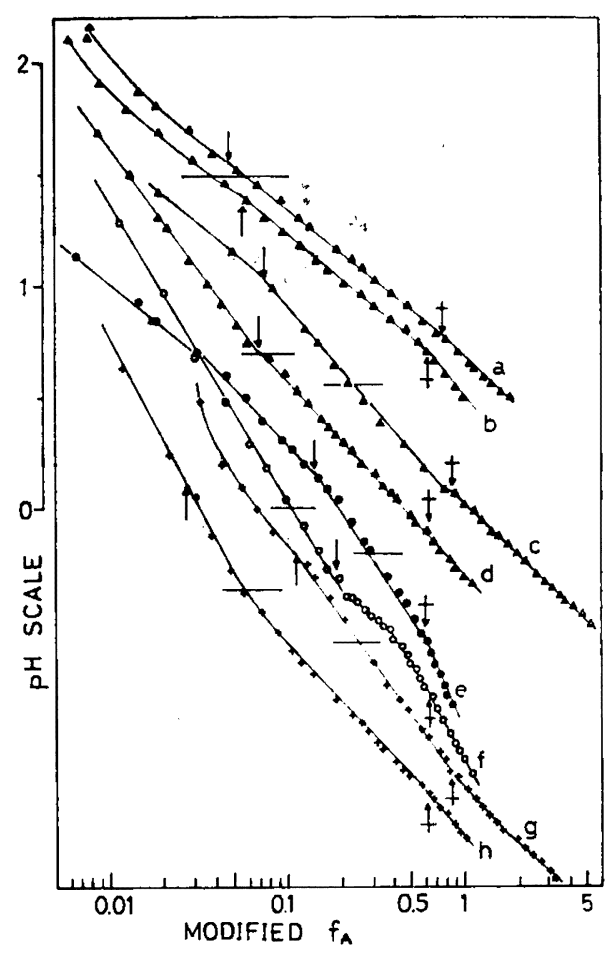

Fig. 2. $\mathrm{pH} v s$. modified $f_{\mathrm{A}}, \frac{f_{\mathrm{A}}}{1-(1-r) f_{\mathrm{A}}}$.

$\uparrow, f^{*}$, [ester] $=[\mathrm{COOH}] ; \uparrow, f_{\Delta}=1 / 2$, equimolar mixture; $\Delta, \Delta$, formate; $O, \theta$, acetate; + , propionate. Horizontal line across the curve indicates the point at $\mathrm{pH}=4.5$. Content of ester group (mol\%), initial concentration of PVA, and concentration of titrant $(\mathrm{mol} / \mathrm{l}): \mathrm{a}, 4.9$, 0.025 , and $0.082 ; b, 4.9,0.05$, and 0.082 ; c, $7.5,0.01$, and $0.082 ; d, 7.5,0.05$, and 0.082 ; e, 15.8, 0.05, and $0.082 ; f, 20.3,0.05$, and $0.077 ; \mathrm{g}, 11.6,0.011$, and $0.077 ; \mathrm{h}, 2.7,0.05$, and $\mathbf{0 . 0 8 2}$.

mole fraction of PMAA として，これに対する $\mathrm{pH}$ をブロットしたものが Fig. 2 である. modified $f_{\mathrm{A}}$ は $f_{\mathbf{\Lambda}}$ の大きい部分で $\mathrm{pH}$ 曲線の傾きを小さくする効果を むつ，图から明らかなよらにここでは等モル組成に当た る $f_{1 / 2}$ の折点が目たたなななったり消えたりしている. エステル基の少ないるのを除いて，f* の方はめいり上 らな折点として残る場合が数例ある.

\section{$3.1 .3 \mathrm{p} K$ について}

前報2)見たように，滴定データに Henderson-Hasselbach 式を商用して $\mathrm{pH} \sim \log (1-\alpha) / \alpha$ 一たたし $\alpha=$ [PVA]/[PMAA]—をブロットすると PVA(0) では無 


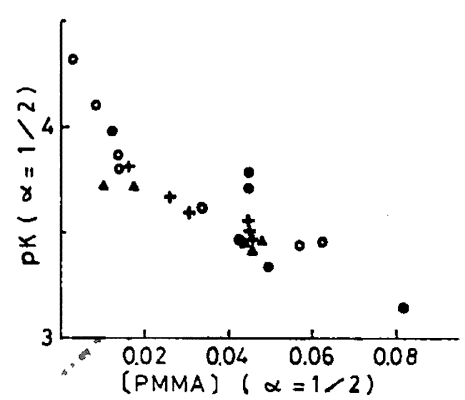

Fig. 3. $\mathrm{p} K$ vs. concentration of PMAA $(\mathrm{mol} / \mathrm{l})$, each at half-seated point (PVA: PMAA =1:2); at room temp., $\alpha=[$ PVA] $/[$ PMAA]; $\triangle$, formate; -, acetate; +, propionate; O, PVA (0)

機塩基と類似の直線群を与える。しかし，エステル基を 有する PVA では幾つかの小弧が連なった裉雑な形にな る.これらもそれぞれに意味をむつと思われるが今はこ れを横に置いて, 形式的に $\mathrm{p} K=\mathrm{pH}+\log (1-\alpha) / \alpha$ とし $\mathrm{p} K \sim \alpha$ ての曲線を描くと，いずれるカルボン酸の半充 塞点 $(\alpha=1 / 2)$ を変曲点とする右下りのS 字曲線を与え ろ. PEG について同様のことを行ってみると $\alpha>0.5$ の 部分については変わらないが， $\alpha<0.5$ の部分では PVA の方が $\alpha$ の增加につれて下に凸の急下降曲線になるのに 対して, PEG では $\alpha$ が 0.2 0.5 まで注䚾一定の, $\alpha=1 / 2$ K挌ける $\mathrm{p} K$ 值のままである点が異なる。 これ を 3.2 での考察と瓶わせて解すれば，

PVA (or PEG) +PMAA $\rightleftharpoons$ PVA-PMAA

$$
\rightleftharpoons(\text { PVA-PMAA })^{-n}+n \mathrm{H}^{+}
$$

の平衡におてて, PEG はPVA よりむ分子全体として は錯合体化しやすいが，一方において酸過䣋の $f_{\mathrm{A}} \leq 0.67$ の領域では PVAを相手にしている場合の方が酸の解雄 が起こりにくいといらことになる。， 凤の $\alpha<0.5$ の 筑囲で PVA と PEG とについての $\mathrm{p} K$ が大きくすれれ るのは $1: 1$ 錯合体と PMAA から生じる復錯合体ある いは鍺㠜集体における集合の仕方の连いを反映するるの であるといえる。

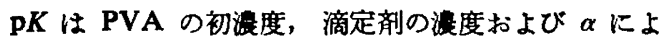
って変るから比較のために半充塞点, $\alpha=1 / 2$ における $\mathrm{pK}$ 值を，その時点に和ける PMAA の䈨度に対してフ ロットして Fig. 3 を得た。四にはエステル残基の量を 記入しなかったが, エステル基の有無, 種類に関係なく $\mathrm{p} K$ はPVAによって「半中和された」酸の灌度と一定 の関係にあるように見える。すなわち，PVA(0) のエス テル化仙 PMAA との相互作用上相手の解離的举野に対

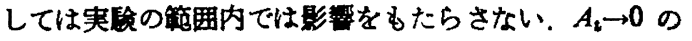
掼限方: $\mathrm{p} K_{0}(\mathrm{p} K$ at infinite dilution without atten-

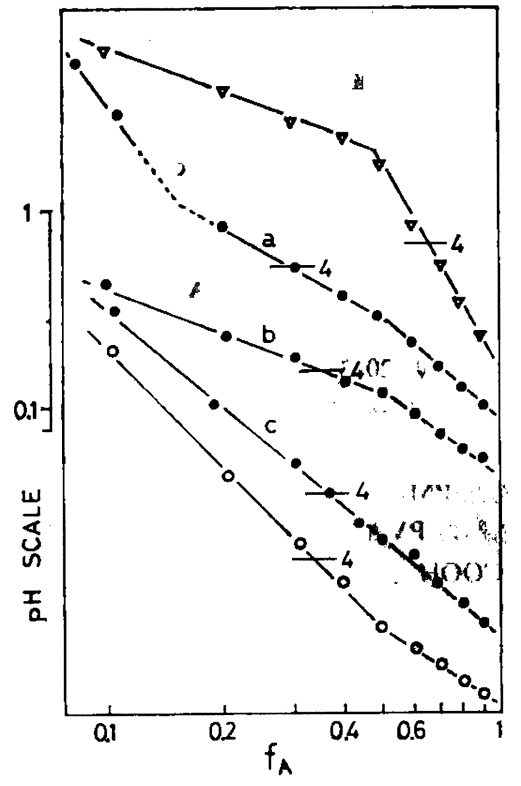

Fig. 4. $\mathrm{pH}$ as a function of mole fraction of acid, $f_{\mathbf{A}}$, in the PVA-PMAA mixture at fixed solute concentration, $0.05 \mathrm{~mol} / l, 20^{\circ} \mathrm{C}: \nabla$, PEG-20000; $O$, PVA (0); 0 , PVA (Ac). Acetyl content: a, 20.3; b, 15.8; c, 12.6 (mol\%).

dant PVA) であり, 無機塩基によろ中和の際の $\mathrm{pK} \sim$ $\alpha$ 曲線はこの $\mathrm{p} K_{0}$ を起点にして $\alpha$ 軸に対称に近い形に なっている点は興味㳭い.

又,ここに見られる $\mathrm{pK} \sim \alpha$ の咸保からすれば, PVAPMAA の 1:1 錯合体において梳 PMAA の解離定数 はかなり大きいるのになるわけであるが，これは水酸イ オンが相手になって現実の解雄が起こる場合の式を中性 高分子の場合に対して形式的に当てはめたことからく る，見掛けの上でだけのことかむ知れず，錯体内で PMAA が本当にそのよらな $\mathrm{pK}$ をむっているかどらか は分からない，しかし、フルコール，エーテルなど電子 密度の高い基と近接して対形成した, 非解離カルボキシ ルからのブロトンの移動は容易たと考えても不合理では あるまい。

\section{2 等流度溶洨混合物の $\mathrm{pH}$}

3.1 の滴定において PVA の初湛度 $L_{0}$ と滴定液であ る PMAA の港度 $A_{0}$ を等しくすると, 式 (1) で $r=1$ になるから, $f_{\mathrm{A}}=$ modified $f_{\mathrm{A}}$, すなわち 3.1.1 3.1 .2 の区別がなくなる．しかて実験的には反応系の容量に制 限があるので,ここではアセチル化物のみについて各ネ 0.05 (base $\mathrm{mol} / \mathrm{l}$ ) の溶液の $f_{\mathrm{A}}=0.1 \sim 0.9$ の混合溶液 をつくってその pH を测定した. PEG は PMAA に対 


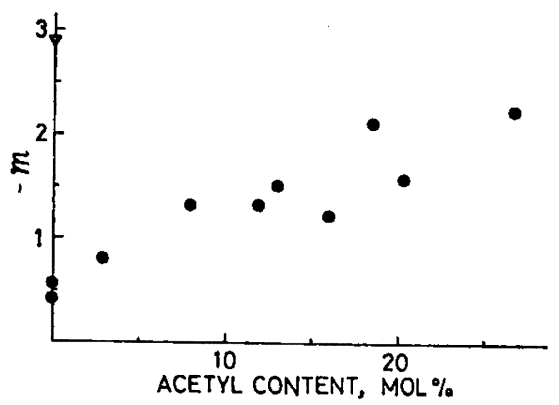

Fig. 5. Slope, $-m$, of $\mathrm{pH} \sim \log f_{\Lambda} \quad\left(f_{A} \geq 0.5\right)$ curve in relation to acetyl content of PVA in the PVA-PMAA mixture; $0.05 \mathrm{M}$ each, at $20^{\circ} \mathrm{C} ; \nabla$, PEG-20000.

して PVA よりも強く錯合することが分かっている゙か らこれについても同様の条件で実験した，結果を Fig. 4

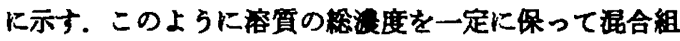
成を大楅に変えると $1: 1$ 錯合体のイメージはいっそ5 めいりょ5になる. $f_{\Delta}$ が 1 から 0.5 へかけての領域に ついて右端から左へ移行するときの直線の傾きは，ボリ カルポン醉中に中性高分子が入ってその解離を抑える能 力を表していると見てょい，この部分を $\mathrm{pH}=-m \log$ $f_{\mathbf{A}}+b$ の式に当てはめてその㑯斜を比べると，フセチル 含有量の多いるのが㑯きも大きく,フセチル基はPMAA との相互作用を強めている，あるいは PVA 分子の塩基 性を高めていると言える.あるいは又,フセチル基の少な いPVA 汪どコンパクトな系まり状をしていて PMAA と十分に相互作用に入りにくいとも考えられるが，粘度 的には PVA (0) と PVA(Ac) とで举轩は変わらず， いずれす PMAA 中にわずかに加えられただけで粘度が 数倍高くなる（低いせん断力の場合）ことからこの考え も当たらない.

一方 $f_{\mathbf{A}}$ の小さい領域における直線の㑯斜は過剩 PVA の中にボリカルポン酸が加わって錯合したものの解離能 を表していると考えていよいから $f_{\Lambda}<0.5$ で PEG の 酸捕捉能が取大, PVA(0)が取小である. アセチル基を 有する PVA では中間的であるがフセチル含有量との間 に整然とした闺保はみられず，含有量の多いものでは $f^{*}$ を折点とするように見えるるの (PVA(Ac， 20.3)) もるあ.

\section{3 その他の测定值}

\subsection{1 相対粘度}

PVA-PMAA 系の粘度倿過利の側で大きく上开す ることは先に2) 見たとおりであるが，これを相互作用を 調へる手段の一つとしてバーン化することを試みた。 両成分の同一湍度溶液を混合したときの見城けの粘度 ク

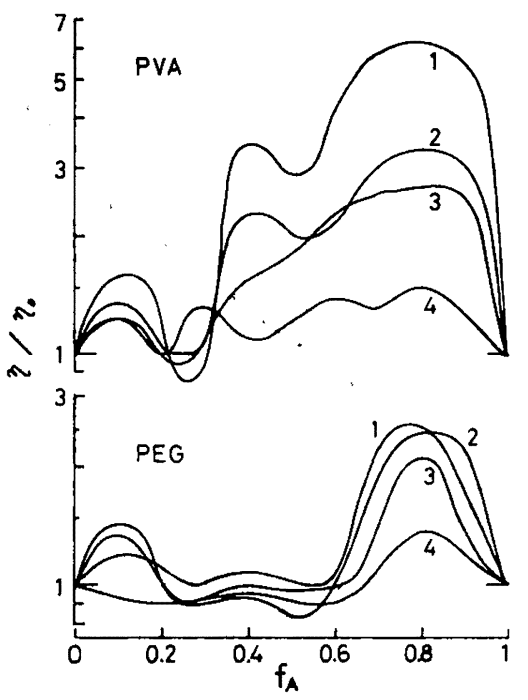

Fig. 6. Relative-viscosity pattern of PVAPMAA mixture. Total concentration of solute $0.05 \mathrm{M}, 20^{\circ} \mathrm{C} ; \eta_{0}=\eta_{\Delta} f_{\Delta}+\eta_{L}\left(1-f_{\Lambda}\right), \eta_{\Lambda}$ and $\eta_{2}$ is apparent viscosity of PMAA and PVA (Ac, 20.3) or PEG. Rotor velocity (rpm) : 1, $5 ; 2,10 ; 3,20 ; 4,100$.

を，それぞれの純成分の溶液粘度のモル分率による加成 生を仮定した仮想的な基準粘度 $\eta_{0} ， \eta_{0}=\eta_{A} f_{\mathbf{L}}+\eta_{\mathbf{L}}(1-$ $f_{\mathrm{A}}$ )—ただし $\eta_{\mathbf{A}}, \eta_{\mathbf{L}}$ はそれぞれ酸と中性高分子の粘 度， $f_{\Delta}$ は混合物中の酸のモル分草一一で除した相対粘 度, $\eta / \eta_{0}$ ，を $f_{\Lambda}$ に対してプロットする．Fig. 6 に相互 作用の大きいPEG と PVA(Ac, 20.3) についての例 を図示する.ここには示さなかったが PVA(0) の场合 とも共通して，いずれすほぼ同じ $f_{\Delta}$ の位腰に大小二つ の依大をるった形になる。與味あることは PEG，PVA ともに $f_{\Delta}=0.2$, すなわち PVA (or PEG) : PMAA = $4: 1$ のところで相対粘度のローター回轱速度 ( ※せん 断力）侬存性が小さく, 錯合体の粒子が剛直でしかも低 粘度なことである. PEG についてはそれ以降 $f_{\Delta}=0.5$ を過ぎるまで粘度の低いままであることと，その領城で $\mathrm{pK}$ が一定値をとることとの間には深い相関があるに違 いない, 又, $f_{\mathrm{A}}=0.2$ の組成の所では, PVA のアセチ ル含有率が 5 20 mol\% の試料のいずれもが見掛けの 比容稀に原大値をるっていることから単錯合体ないし包 摄的棈造を瞕示している. PVA の場合には全体として 凝集体は大きいが壤れやすい棈造であるようにみえ， 1:1 組成の場合にも PEG-PMAAにみられるはどの安 定泩はない.

\subsection{2 端度}

Fig. 7 に PMAA 水溶液ならびに $0.049 M$ PVA 


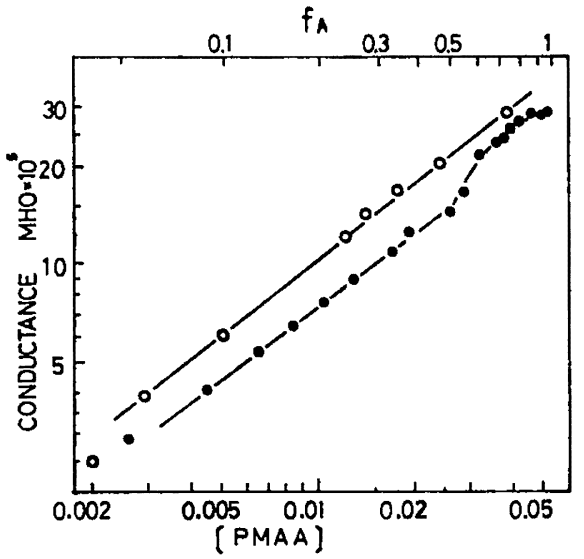

Fig. 7. Electric conductance of aqueous PVA (Ac, 12.4)-PMAA (O) and of PMAA (O); at $20^{\circ} \mathrm{C}$.

(Ac, 12.4) -0.053 M PMAA 混合物の電導度を掍げ る.高分子酸としての䈨度は同じであっても PVAの

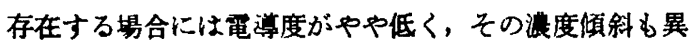
なる（（電導度の酸䈨度依存性はそれぞれ曲線の傾きか ら水中において [PMAA] ${ }^{0.8}$, PVA の存在においてて $f_{A}$ $\leq 0.5$ で [PMAA] 0.78 であり, ベキ数が 4/5, 3/4 と単
純な值が得られるが，等モル組成を超えて酸が多い部 分は夜雑な闺係になる.) 両成分の化学構造から考える と，互に水来結合をする相手のある間は一一前提として structural complementarity はあるものとして一高 分子酸は相手のPVA と錯合体をつくってその一部が電 萁に阅与するのに対して，等モル以降に加入する酸は柾 水結合によって equimolar polycomplex との间传合 錯合体を形成するか，または遊離状態で存在するかはと むかく，全的に関与するといってよい，粘度などからす れば前者の裉錯合体化していると考えるのが妥当である 5 .

\section{文触}

1) I. V. Savinova, N.A. Fedoseeva, and V.P. Evdakov, V'ysokomol. Soedin. Ser. A, 18, 2050 (1976).

2) 城内裕治，高分子端文集，34，521 (1977).

3) 侧えば, T. Moritani, Y. Fujiwara, Macromolecules, 10, 532 (1977).

4) Kh. S. ハシグダサリヤン,“ラジカル重合の理智”, 井本 稳, 二見成共訳, 朝合春店, 1964, p. 127.

5) I.M. Papisov, Ts.I. Netyalkova, N.K. Avratchuk, and V.A. Kabanov, Vysokomol. Soedin. Ser. A, 15, 2003 (1973).

Potentiometric Titration of Partly Esterified Poly(vinyl alcohol) with Poly (methacrylic acid) in Aqueous Solution*

Hiroharu HoRIUCHI*1

*Studies on the Interaction of Polyelectrolyte and Non-electrolyte. II.

*1Department of Chemistry, Faculty of Science, Ehime University

(Bunkyo-cho 2, Matsuyama, Ehime, 790 Japan)

Aqueous poly (vinyl alcohol) (I), partly esterified with formic, acetic, or propionic acid, was potentiometrically titrated with poly (methacrylic acid) (II). Plots of pH of the solution against mole fraction of the acid in the system show connected straight lines (or gentle curves) and the breaking points correspond to the characteristic compositions of components and/or their complex. At constant solute concentration the pH-curves for the mixture lead to conclude that, as a whole the ester group makes the I more basic and accessible to II, but it vitiates structural complementarity and accelerate the dissociation till the carboxyl group equals ester residue. In the regions covered by experiments, however, I and II form an equimolar polycomplex. Results from the conductance measurements support this. Relative viscosity pattern of I-II mixture will be a measure of aggregation in the system.

KEY WORDS: Partly Esterified Poly (vinyl alcohol) / Poly (methacrylic acid) / pH-Titration / Poly(electrolyte-nonelectrolyte) Complex / Conductance / Relative Viscosity Pattern /

(Rcceived August 9, 1978: Accepted November 1, 1978)

[Kobunshi Ronbunshu, 36 (5) , 287-292 (1979)] 